\title{
PARTICIPATION: HOUSING AND URBAN VIABILITY
}

\author{
Malcolm Miles \\ School of Architecture, Design and Environment, University of Plymouth, \\ Drake Circus, Plymouth PL4 8AA, UK \\ E-mail:M.F.Miles@plymouth.ac.uk
}

Received 10 April 2013; accepted 21 June 2013

\begin{abstract}
In the global North, housing tends to be seen as a sub-sector of the construction industry. In the global South, in contrast, it might be considered more as a verb - housing as the activity of meeting basic needs for shelter. As such, this process is frequently undertaken by users themselves, in the informal settlements which surround most cities. While these settlements were once regarded as a threat to the urban order (or urbanization), today there is increasing recognition that self-build and self-managed housing meets the needs of urban development in ways which are usually more sustainable as well as lower-cost than standard housing schemes (whether in the public or the private sector). This paper begins from the question as to how far the lessons of informal settlements in the South can be applied in the North. It looks at the status of informal settlements in the new South Africa, and at two schemes in the UK: the Coin Street development in London, managed by tenants; and Ashley Vale self-build housing in Bristol, in southwest England. These are not seen as exemplary but simply two cases which can be compared and contrasted in the terrain of new approaches to building cities for the future.
\end{abstract}

Keywords: housing, sustainability, participation, social change.

Reference to this paper should be made as follows: Miles, M. 2013. Participation: housing and urban viability, Journal of Architecture and Urbanism 37(3): 218-225.

\section{Introduction}

Like any other sector of construction, housing is produced according to prevailing economic, social, political and cultural imperatives. In a period of austerity, following the financial crisis of 2008, housing has, like other sectors of development, been subject to a decline in volume. As real incomes drop, and mortgage finance is more difficult to obtain, selfbuild housing may become attractive to those who have the time, the inclination and access to the necessary skills, to undertake it. At the same time, when urban development has been largely handed to the private sector in a political and economic climate of neoliberalism, the shock of 2008 and the broad distrust in private enterprise which it engendered may lead non-privileged urban dwellers to ask what alternatives exist to market-led development. All this is in context of a rapid growth in cities in the global
South, and a growing (if uneven) recognition that informal settlements - far from being a sign of urban chaos - may offer a distinct form of ordering, and social and economic benefits for those involved. It may also be that elements of the process evolved in the South could inform future urbanisation in the North, though this requires a cultural adjustment which many professional experts (planners, architects, urban designers, engineers) and elected representatives (councillors, members of parliament) and, indeed, many dwellers, may not wish to make. Nonetheless, the lessons are there. In this paper I investigate the current status of informal housing in post-apartheid South Africa, and two schemes in the U.K.: the Coin Street development in central London; and Ashley Vale self-build housing in Bristol, in the south-west of England. South Africa is an interest- 
ing case because, after the end of apartheid, the new state has adopted some urban policies echoing those of the North while retaining a substantial reservoir of self-build skills from townships which were regularly cleared and then rebuilt under the old regime. Of the two schemes in the U.K., the former has been managed by tenants of social housing within the scheme for some decades; the latter was constructed in the 2000 s, managed by a local voluntary group. While Coin Street has extended to several largescale blocks, in a prime site on the south bank of the Thames (near the Royal Festival Hall and South Bank Arts Centre), Ashley Vale occupies a redundant industrial site bordered by a railway embankment. Together, the three cases offer an opportunity to compare and contrast their processes and outcomes, from which to ask whether such initiatives indicate a path to more sustainable and socially-owned cities in the future - a future now almost certainly under threat from climate change and a potential shrinking of the available habitat for human (and non-human) habitation, creating a greater need for innovation in the development of high-density urbanisation.

\section{Informality in the wnew South Africa}

Urban policy in post-apartheid South Africa has moved in two directions: first, recognition that selfbuild housing is beneficial, leading to state-sponsored improvements; but second, a policy to clear all informal settlements by 2014. These directions are incompatible and have arisen in different areas of urban and national governance, the first more informed by the actualities of expanding an population and its (often unmet or partially met) housing need; the second at a national level as the state seeks to emulate the developed world (as it is called) and to become a leading economic power in the region. Looking to the former, the 'City of Cape Town Five-Year Integrated Housing Plan' (2011) predicts a population increase of $13 \%$ by 2030 , and seeks to address the prospect of an 'uncontrolled growth of informal settlements and backyard shacks' (City of Cape Town 2011: 40). Backyard housing uses plots within existing development, creating higher density and mixed standards of construction, often involving unreasonable exploitation by landlords and existing tenants. It is attributed to the length of time poor households wait in the housing queue, and their consequent desperation (City of Cape Town 2011: 44). The range of housing which has arisen after the period of the townships - self-build settlements which grew spontaneously and were regularly demolished under apartheid - is described by planner Nisa
Mammon and architect Katherine Ewing as, 'single, free-standing middle-income housing, backyard or free-standing shacks, 1 to 4 storey hostels and singlestory row housing units' (Mammon, Ewing 2005: 3). Aware of the length of its housing lists, Cape Town has decided to upgrade informal housing and backyard squats by providing them with basic services (such as water, drainage and power lines). This legitimises informal building regardless of national policy, using the standard processes of local government development such as inviting tenders for the work, carrying out surveys, and drafting business plans for pilot schemes. The Plan proposes the establishment of area committees 'to engage local stakeholders' while 'the City will provide basic services which are equitable and sustainable, maintain them, assess the effectiveness of the project through monitoring its implementation, and roll it out further (Mammon, Ewing 2005: 3). Offices will be set up within settlements to foster links to residents and such NGOs as operate in the vicinity, seeking 'incremental improvement of the entire living environment' to reflect needs 'identified by the communities themselves' (City of Cape Town 2005: 46). At the same time, the City will buy 150-300 hectares of land for building new, low-cost housing while further affordable housing is to be provided by selling serviced plots at subsidised prices to low-income families 'to build their own homes piecemeal' with the support of sample building plans and connected services (City of Cape Town 2005: 59).

Cape Town's urban policy indicates a liberal and progressive approach to social housing after the trauma of the overtly racist policy of informal settlement demolition under apartheid. It is not, however, a matter of an entirely sudden shift. There were a few precedents within the old culture, just as the political process towards a new South Africa did not happen overnight. In the last years of apartheid, then, some white architects began to work with township groups on pilot projects using kits of parts for assembly by dwellers on site (Coetzer 2012: 33-35). Architect Nic Coetzer writes that the clean lines of modernism, and 'its zoning and sanitation mania', suited apartheid's taste for an ordering offering clear definitions and boundaries, so that, "it followed logically that "soft modernism" could work equally effectively in undoing ... the damage of that policy' (Coetzer 2012: 3). Soft modernism means, here, the way in which provision of a kit of parts and basic installations for self-build schemes does not fix the scheme's outcome but offers flexibility in the arrangement and function of spaces according to changing needs. But the debate on housing in South 
Africa also echoes calls for improved public spaces as are encountered in cities in the North, if for different reasons. For Ewing, for example,

... the primary spatial structure' for low-income development should include 'positive public spaces, green systems, transportation networks with emphasis on non-motorised transport, community amenities and human-scale local interventions for informal and formal economic and social activities (Ewing 2005: 1).

This follows the place-making initiatives of architects Roelef Uytenbogaaardt and Norberg Rosendal under apartheid; and Cape Town's Dignified Places Programme more recently (City of Cape Town 2003). The latter is promoted by urban designer Barbara Southworth as a provision of incomplete sites which can become the 'armatures' of a scheme which is then 'interpreted, inhabited and added to by the communities that use them' (Southworth 2010: 106). Among the elements provided here were colonnades and street furniture, reflecting a conventional approach to urban design in designating spaces for gathering, sitting, and taking advantage of the shade. For Coetzer, however, this reduces architecture to 'edged squares, colonnades, low walls to sit on', not merely for convenience but specifically as 'a disciplining device' to subdue 'the unruly and ill-formed body of the post-apartheid city' (Coetzer 2012: 4-5). Coetzer traces the strategy's origin to Uytenbogaardt's use of trabeated colonnades and verandahs in the previous era, which can be easily manufactured as readymade components.

This is interesting. Coetzer's criticism is not merely that architecture is reduced to the activity of providing simple components - to me this seems not entirely unlike the design of flat-pack furniture applied on a larger scale for open-air sites - but also that the functionalism which this form of provision suggests, however well-intended, lessens the role of a scheme's users in determining its spatial functions for themselves. This puts the debate in context of critiques of post-war social housing projects in the North, where well-intended and relatively well-resourced schemes are, still, marred by over-functionality. In his review of the Thamesmead Estate on the south-eastern periphery of London (England), for instance, urban designer and theorist Edward Robbins writes of the ignorance of progressive planners and designers of the complex yet relatively stable self-ordering of the inner city street, and of the way in which an over-functionalised architecture such as Thamesmead's rigidly defined and bounded sites for living, parking, leisure and so forth - becomes a statement of a 'deep distrust of working- and lowerclass life' which is transposed to 'the physical condition of the neighbourhood' (Robbins 1996: 289). Robbins continues that, 'Without realizing it, planners and designers in condemning the space of working-class life were saying that the working class should not be allowed to reproduce any of the spontaneous, chaotic and serendipitous social interactions of the traditional street' (Robbins 1996: 289-290). Can this criticism be translated into a refusal or an inability on the part of South African urban designers and planners today, despite their good intentions, to accept that what outwardly seems chaotic may yet have an invisible order, evident to those who live there but not to professional experts? Looking from outside, it is not for me to say. What I can suggest, however, is that functionalism undermined the modernist project of engineering a new society by design, as Robbins says by taking away from inner-city dwellers the right to determine their own multiple and layered uses of the street (often as extension of restricted domestic space). In a developing country, as seen from the viewpoint of the north (where development has become a norm according to certain paradigms based mainly in economic growth), an obvious need to provide housing and sanitation may be met either by admitting non-professionals to the design process in ways which may fracture its pre-determined aesthetic or functional arrangement, or by seeing design as a process without fixed outcomes, open to extension and unending adaptation by dwellers according to their own perceptions of need. It would be naïve to imagine those perceptions as un-informed by wider cultural currents (as conveyed by global news and entertainment), but it may be both realistic and ethically appropriate to facilitate a learning curve whereby dwellers, suitably supported and drawing on their already established skills (and their expertise in dwelling as they do), take over the process. If this has dangers, it is no less disingenuous than the leap of faith by which a more conventional urban design using parts such as colonnades and seating (as above) is foreseen as generating spontaneous community building, as demonstrated in another pilot project, the Nyanga bath-house, built on the site of cleared informal housing in 2001 only to be informally dismantled in 2004 and replaced by informal housing by 2007 (Coetzer 2012: 6). It appears from all this that Coetzer has a point.

The literature of informal development has, in any case, established that self-built housing has a range of benefits from low-cost and the use of recycled materials to better indications for health, family stability and the pursuit of a viable livelihood than standard (inflexible) government housing schemes 
(Peattie 1968; Turner 1976; Berg-Schlosser, Kersting 2003). Development architect John Turner advocated provision of sites and basic services for locally initiated self-build housing at a United Nations seminar on Uncontrolled Urban Settlements in 1966 (Ward 2000: 47). And sociologist P. K. Mutagi argues that the failure of some development projects initiated by international aid agencies and NGOs looking from a 'developed world' perspective has been due to a 'lack of participation from the beneficiaries and poorly managed delivery' which does not enable investment to reach the poor for whom it is intended (Mutagi 1998: 53). As Mutagi continues,

... technology and financial aid may be part of development but they are only small parts. More significant are the people's determination to make things better for themselves; the accountability of those in power to those they propose to help develop; people's willingness to change their cultural patterns, their administrative patterns, their educational systems and sometimes their political systems. These are all parts of development. Development involves changes in all aspects of any system which is developing (Mutagi 1998: 53-54).

The question, next, is whether, since self-build housing was piloted in London in the 1970s by architect Walter Segal (Segal 1982, 1955; Blundell Jones 2009), efforts and outcomes in the global South will suitably inform the next or future phases of urbanisation in the North.

\section{Ashley Vale}

Ashley Vale, Bristol (also known as The Yard after the brownfield site it occupies) is a recent self-build housing scheme on a redundant scaffolding yard two miles from the city centre. The site is quite enclosed, in a low-lying area bordered by railway embankments on two sides and accessed via a short tunnel. The project was initiated by the Ashley Vale Action Group (AVAG), and is adjacent to a street of nineteenth-century terraced housing and a range of small business premises. Before the scaffolding yard, the valley had been a site of watercress beds and the area retains a semi-rural appearance, with small plots of flowers and vegetables cultivated by residents. Today there are 31 houses in a range of styles, shapes and colours, some quite large, using a timber-frame and cladding system like that developed by Segal in London in the 1970s (cited above). When other structures were dismantled as the yard closed, a concrete base remained and has been used as a foundation for the new houses. The office block has been refurbished to high environmental standards, winning the South West Green Energy Award for housing in 2000. The ground floor provides community facilities. Among improvements are a solar and wood-powered heating system, and reduced window size and double glazing. The office conversion was managed by Quoin Commonhold Association, formed as an off-shoot by AVAG with six additional individual members. The first twenty houses were built by dwellers, who bought their plots from AVAG; the second phase of five houses was built to shell stage by AVAG for completion by dwellers. The same system was used for six apartments on the top floor of the office building. For those with time and access to skills, but a low income, a complete self-build project offered possibly the only avenue to home ownership. For those with more money, a shell scheme offered flexibility as to how the interior was configured, with the option of future changes within the timber-frame structure.

Ashley Vale has not been trouble-free, however: although it has gained publicity for its environmental credentials, the site's development has undergone some unplanned shifts. A housing association which acquired plots for elderly housing was unable to deliver that part of the overall scheme, after which Quoin was formed to take on these units. Journalist Sarah Edghill reported, too, that while the area previously attracted artists, circus performers and those seeking to evolve alternative lifestyles, many of whom joined AVAG to prevent the yard's development by a volume house builder, some existing residents became anxious when they saw the size of some new homes, and were worried that owners might sell them on at a quick profit (Edghill 2005). She quotes one selfbuilder, 'We weren't experienced enough to insist that certain conditions were set down in writing. We are trusting sorts of people and just wanted to get this project going and improve our community ... we've made mistakes [but] everything was done in good faith' (ibid). This contrasts to a higher level of experience at Coin Street, as discussed below, where some members of the cooperative which managed the scheme had previous experience of community organising or property development. Nonetheless, Ashley Vale was viewed by the Commission for Architecture and the Built Environment as 'an impressive self-build project ... [with] a distinct character with a mix of scales, architectural styles and materials, and pleasant public spaces' (CABE 2011).

Compared to standard housing, either from volume builders or on the housing market, costs at Ashley Vale were modest. The land was purchased in 2001 for $£ 605,000$. Dwellers paid between $£ 35,000$ 
and $£ 45,000$ per plot according to size, with basic services (water, drains, power) provided much as they are in such schemes in the South. Building costs ranged from $£ 35,000$ to around $£ 100,000$. The cost of a new house was thus from $£ 70,000$ to $£ 145,000$, around half the cost of equivalent size and quality houses built or refurbished by property developers, with the advantage of a distinctive design style, flexible spaces, and membership of a coherent social group. Most of these houses were bought by first-time buyers for whom a dedicated mortgage arrangement offered $100 \%$ loans if they had no capital, though the money could not be released until full planning permission (requiring a detailed design) was gained, taking up to a year. The shell, self-finish homes were sold at $£ 150,000$ and required $£ 15,000$ to $£ 30,000$ to complete. They are valued at $£ 225,000$ today (2012), and the first phase at $£ 250,000$ to $£ 350,000$. This puts these homes out of reach of future first-time buyers should they be put on the market. But AVAG see the scheme's benefits as,

Light-weight timber framed houses that could be supported by the existing concrete raft proved very efficient and adaptable to individual needs. Sustainability has been addressed in various ways, including insulating to better than Building Regulations requirements, and installing solar panels and a community pellet boiler for the six apartments. The self-builders formed a close bond, helping, advising and assisting one another; they feel they have built a community along with their homes (AVAG 2011).

Despite massive differences in conditions, I wonder if there are some similarities between Ashley Vale and self-build schemes in the South. Although self-builders in Bristol had to acquire the skills which were honed over decades in South Africa, and were from a more prosperous and socially mobile background (in a city which is fairly cosmopolitan), they have demonstrated the viability of flexible housing design using a basic shell, combined with the use of low-energy technologies. This sets a precedent which, in theory at least, could be used and adapted for any urban brownfield site in the North, subject to planning consents and so forth. Perhaps the lesson works in both directions, too: if the new South Africa seeks - for reasons which it is easy for progressive external commentators to criticise - to emulate the appearances of development in the North, then the growth of self-build schemes in the North might reassure authorities in the South as to the appeal as well as practicability of such projects. As Mutagi argues (above), participation underpins a sense of ownership by which any scheme is more likely to succeed. If modernism overlooked the implicit but invisible order of the inner-city street, it may now be possible to reclaim a sense of that multi-layered social self-ordering in schemes such as Ashley Vale. This is not to say that Ashley Vale is the Garden of Eden; it is likely to have (and to an extent has had) the same strains and conflicts of interest as any urban neighbourhood. It is too early to say how it will accommodate them.

\section{Coin Street Community Builders}

Modernist architecture had a utopian, and to an extent a socialist, strand. Karl Marx-Hof in Vienna was a product of modernist planning, designed by Karl Ehn, a follower of modernist architect Otto Wagner, and was called the Ringstrasse des Proletariats. Architecture critic Jonathan Glancey sees it as a 'courageous example of socialist housing' (Glancey 2007: 30). Karl Marx-Hof was influenced by the planners of the London County Council in the 1920s, the successor to which was the Greater London Council in the post-war period. One of the GLC's last acts before its abolition by Margaret Thatcher in the 1980s was to put planning constraints limiting the commercial value of the site of a redundant factory on the south bank of the Thames. This enabled the Coin Street Action Group, a non-profit company formed by local social housing tenants, to safeguard the housing rights of local people in a period of profit-centred redevelopment. The action group bought the site, worked with architects to draw up a plan and gain the necessary permissions for a mix of social housing and private-sector retail outlets. The outcome is now sometimes known as the Oxo Tower, from the old factory (manufacturing beef stock cubes) and the new, fashionable restaurant which is now housed on the top floor, with views across and down the Thames.

In 1984, as the scheme began, the action group became Coin Street Community Builders (CSCB). The first project completed was the Mulberry Housing scheme, adjacent to a market at Gabriel's Wharf, an open site adjacent to the tower which is now a site if small design businesses, bars and cafés. The second phase was Palm Housing Cooperative, also adjacent, followed by the completion of redevelopment at Oxo Tower in 1995. The project continues.

Walking into the area, a spectator sees a typical waterfront development of apartments, art galleries, design shops, boutiques, bars, and food outlets in refurbished buildings. On the waterfront at ground level the Oxo Tower covers part of a continuous pedestrian route from the South Bank Arts Centre via Tate Modern to Shad Thames (an area of gentrified housing in old 
warehouses by Tower Bridge). Coin Street is social housing for 1,000 people, managed by housing cooperatives, however, and not part of a developer's gentrification project. While, today, the London Borough of Southwark (in which Tate Modern is located) actively seeks to remove social housing from sites - such as the Heygates Estate - too near the city's financial district, as they see it, in a process which reveals a significant democratic deficit, Coin Street is run by its residents and its management structures responsive to the needs of dwellers.

Though common in many parts of Europe, the cooperative model is unusual in the U.K. New tenants are not expected to have previous knowledge of housing management but do have the opportunity to take part in decision making; and are offered training to build their skills and capacity for this (Future Communities 2012). Public spaces on the embankment are managed by another non-profit company, the South Bank Employers' Group. A neighbourhood centre opened in 2007, designed by architects Haworth Tompkins, offering child care, youth clubs, access to hospital midwifery services, a CSCB office and community programmes. Income from the hire of conference rooms supplements public grants.

In terms of sustainability, the cooperative model offers stability and long-term development with a focus on housing, and fosters emotional ownership by as cooperative members. This does not mean that CSCB represents tenants as such, but it is accountable to tenants formally through its decision-making Board and informally because all members of the Board (apart from a small number co-opted for their professional expertise) live there. Interviewed by journalist Andrew Bibby, Iain Tuckett, CSCB Director and member of the original action group, said, 'If people in one of the co-ops are unhappy, that's a real problem for us ... We call ourselves community builders ... trying to build a community that works. ... We're very close to the ground.' (Bibby 2012). In contrast, the Shard, London's newest icon, is seen by commentator Aditya Chakrabortty as a sign of how 'London is becoming more unequal ... dependent on hot money' (Chakrabortty 2012). Apartments in the Shard cost $£ 30$ to $£ 50$ million, which could buy two hundred houses at Ashley Vale, a new hospital, or a major work by Picasso. Strange days ...

\section{Reflections}

A question emerges: should the ordering of urban space and habitation be determined by dwellers to meet their needs or by the market? Put like this, the choice is over-simplified, omitting the role of the nation-state in safeguarding the common good (a role which states seem more or less to have abandoned in an urge to be market-friendly). A second question, then, from the experience of South Africa, is whether the common good can be achieved by the authorities, or requires coproduction by dwellers whose expertise on dwelling is valued alongside that of professionals on planning and design. A third question, from Ashley Vale, is whether seemingly successful experiences at a local level can be transposed to a larger urban scale. To an extent, Coin Street says it can, but was facilitated by a special act on the part of the GLC before its abolition at the onset of a neoliberal hegemony which makes such actions more or less impossible in today's climate of deregulation. Perhaps what can be said with some confidence is that design alone is not a solution to urban housing needs. To the extent which it becomes de-politicised, ignoring the utopian strand of modernist planning, design tends to favour top-down solutions (as if community could be design into a scheme). In this light, planner Marie Huchzermeyer cautions against overvaluing the visible, and argues for a 'thorough analysis of the causes of the housing backlog or of settlement informality' in South Africa (Huchzermeyer 2010: 144). Issues such as poverty would be revealed in such analyses, but there could be a danger, too, of looking only at socio-economic aspects of the situation, enforcing the status of the poor as victims, when a policy which enables non-privileged groups within a society to take housing matters into their own hands may be empowering democratically as well as materially.

The importance of participation was emphasised in the 1960s by Egyptian architect Hassan Fathy in his scheme for a new urban development at Baris, near the Kharga Oasis, in 1965. Fathy was asked to design a settlement which would attract villagers to migrate to it rather than to Cairo, when Egypt faced (as it still does) a rapidly increasing population and a steady move of population to its capital city. As in his previous (and flawed) project at New Gourna near Luxor in the late 1940s (Fathy 1969; see also Miles 2006), Fathy again used mud-brick as a low- (or no-) cost material, proposing that groups of dwellers could collaborate to build their homes. Fathy was a nationalist for whom the import of Western technologies maintained colonialism:

The only alternative is to resort to the traditional cooperative system by finding means to make it work under the non-traditional conditions prevailing nowadays. The snag in cooperative building is that one man cannot build a house, but ten men can build ten houses easily (Fathy 1985: 92). 
This is, similarly, the lesson of schemes such as Ashley Vale, while Coin Street demonstrates that collective working can apply to management as well as to building.

This is not to say that community architecture, as it has generally developed in the North, is an answer to urban development. Too often, participation is a sop to local groups rather than the point of departure. Architect Jeremy Till recalls a meeting on a community centre in a 'blighted neighbourhood' where, he explains, the transaction was 'we give you money; you give us back improvements' while hope 'that fractured territories can be re-consolidated' was forlorn (Till 2005: 23). Till sees a need to understand 'the contingency of the given, in its very uncertainty and openness ... as an opportunity and not a threat' (Till 2009: 191). He looks toward a negotiated balance of power between users and architects. Participation is effective, he argues, when it is accepted that it is embedded in an agonistic politics in which groups contest (sometimes incompatible) claims for space. The architect or designer, however, will need to relinquish power and privilege while retaining specialist knowledge:

The action of the architect is here not about the implementation of generic solutions to particular problems. It is not about the architect as the detached polisher of form and technique, but as the person who gathers the conflicting voices of a given situation and makes the best possible social and spatial sense of them. Hope is not discovered in the clouds ... hope is founded in the interstices of the given (Till 2009: 193).

In this vein, planning academic Leonie Sandercock writes, 'a society need not be committed to a particular vision ... then ask how much diversity it can tolerate' but can adopt a political life which is 'dialogically and agonistically constituted' (Sandercock 2006: 49).

The extent, finally, to which such ideas inform present and future urbanization is at root a political question, aligned to issues of democracy and its deficit in neoliberalism. But perhaps the neoliberal bubble began to burst in 2008, and as the fantasy of a world ruled by market forces unwinds then increasingly direct forms of democratic decision-making may emerge.

Peter Hall writes in Cities of Tomorrow, that the cultural turn in planning since the 1980s - which accompanied the rise of neoliberalism in townscapes which were, primarily, visual and aesthetic spectacles - has relegated housing as an issue to a 'deep background' of intractable issues (Hall 1996: 416). He sees a denial of social factors as marginal groups are 'damned up in the cities, where they will perhaps be housed after a fashion ... in but not of the city' (Hall 1996: 422). As the millennium approached and plans for celebration took shape (notably in the ill-fated Millennium Dome designed by Richard Rogers), he saw a deep pre-dawn chill.

After the millennium, that chill has deepened into a fracturing of cities into gentrified and residual zones. Meanwhile, in the U.K., design for social housing schemes - increasingly out-sourced to developers as a ration of affordable homes within market-led developments - has reverted to the 1970s North American notion of defensible space (Newman 1973). In context of a War on Terror, after the Cold War, design is increasingly shaped by notions of urban dereliction which, I would argue, are inherently anti-urban in content. The city is taken as a crime zone contrasted to a rural idyll, and design responds to this before it responds to the need for an environment which is conducive to wellbeing. British journalist Anna Minton recalls a visit to an award-winning housing scheme: 'small windows, a reinforced steel door with a full-size iron gate ... and a grey aluminium roof with a military feel to it ... security grilles, electronic security, anti-climbing paint and perimeter fencing ...' (Minton 2009: 73). It looks like a prison: this is anomie; another world is possible.

\section{References}

AVAG. 2011. Self-build portal website [online], [cited 15 August 2012]. Available from Internet: www.self-buildportal.org. uk/ashley-vale

Berg-Schlosser, D.; Kersting, N. (Eds.). 2003. Poverty and democracy - self-help and political participation in third World cities. London: Zed Books.

Bibby, A. 2012. [Online], [cited 21 July 2012]. Available from Internet: www.andrewbibby.com/socialenterprise/coinstreet.html

Blundell Jones, P. 2009. Sixty-eight and after, in P. Blundell Jones, D. Petescu, J. Till (Eds.). Architecture and participation. Abingdon: Taylor and Francis, 127-139.

Chakrabortty, A. 2012. [Column]. The Guardian 26 June, G2: 5.

Commission for Architecture and the Built Environment (CABE). 2011. [Online], [cited 15 August 2012]. Available from Internet: http://webarchives.gov.uk/20110118095356/http

City of Cape Town. 2003. Creating a dignified city for all: the City of Cape town's Uluntu Plaza - dignified places programme, Programme Review Report. Cape Town, City Urban Design office.

City of Cape Town. 2005. Five Year Integrated Housing Plan 2011/12 - 2015/16. Cape Town, City of Cape Town (Planning Department).

City of Cape Town. 2011. Five-Year Integrated Housing Plan 2011/12-2015/16. Cape Town, City of Cape Town.

Coetzer, N. 2012. Architecture and Armature: "Dignified Places" in post-apartheid Capetown (unpublished paper supplied to the author). 
Edghill, S. 2005. Sweet dreams turn sour in Ashley Vale, Daily Telegraph 19 March [online], [cited 15 August 2012]. Available from Internet: http://www.telegraph.co.uk/property/3340253/Sweet-dreams-turn-sour-in-Ashley-Vale.html

Ewing, K. 2005. The design of positive public space as a core public investment in low-income housing areas: examining the possibilities for a market space and infill housing in Khayelitsha, Cape Town, in IAHS World Congress on Housing conference "Transforming Housing Environments through Design", 27-30 September, 2005, Pretoria, South Africa.

Fathy, H. 1969. Gourna: a tale of two villages. Cairo: Ministry of Culture.

Fathy, H. 1985. Baris case study, in J. M. Richards, J. Serageldin, D. Rastorfer (Eds.). Hassan Fathy. Singapore: Concept Media. $92 \mathrm{p}$.

Future Communities. 2012. [Online], [cited 21 July 2012]. Available from Internet: www.futurecommunities.net/case-studies/coin-street-london-1984-present

Glancey, J. 2007. Modern architecture: the structures that shaped the modern world. London: Carlton Books.

Hall, P. 1996. Cities of Tomorrow. Oxford: Blackwell.

Huchzermeyer, M. 2010. Pounding at the tip of the iceberg, Politikon 37(1): 129-148. http://dx.doi.org/10.1080/02589346.2010.492153

Mammon, N.; Ewing, K. 2005. Moving towards a design approach to low-income housing in urban Cape Town: the case of Joe Slovo Park, in IAHS World Congress on Housing conference "Transforming Housing Environments through Design”, 27-30 September, 2005, Pretoria, South Africa.

Miles, M. 2006. Utopias of mud? Hassan Fathy and alternative modernisms, Space and Culture 9(2): 115-139. http://dx.doi.org/10.1177/1206331205285852

Minton, A. 2009. Ground Control: fear and happiness in the twenty-first century city. London: Penguin.

Mutagi, P. K. 1998. Sustainable development - a third world perspective, in B. Hamm, P. K. Mutagi (Eds.). Sustainable development and the future of cities. London: Intermediate Technology Development Group.

Newman, O. 1973. Defensible space: people and design in the violent city. Oxford: Architectural Press.

Peattie, L. 1968. Reflections on advocacy planning, Journal of the American Institute of Planning 31(4): 331-338.

Robbins, E. 1996. Thinking space / seeing space: Thamesmead revisited, Urban Design International 1(3): 283-291. http://dx.doi.org/10.1080/135753196351047

Sandercock, L. 2006. A love song to our mongrel cities, in J. Binnie, J. Holloway, S. Millington, C. Young (Eds.). Cosmopolitan urbanism. London: Routledge.

Segal, W. 1982. View from a lifetime, Transactions of the RIBA 1(1): 7-14.

Segal, W. 1955. Home and environment. London: Leonard Hill.

Southworth, B. 2010. Making public space in $21^{\text {st }}$-century Cape Town: an idealistic planning construct or a catalytic building project?, in E. Pieterse (Ed.). Counter-Currents: experiments in sustainability in the Cape Town region. Cape Town: Jacanas Media, 102-107.

Till, J. 2005. The negotiation of hope, in P. Blundell Jones, D. Petrescu, J. Till (Eds.). Architecture and participation. Abingdon: Taylor \& Francis.
Till, J. 2009. Architecture depends. Cambridge, MA: MIT press.

Turner, J. F. C. 1976. Housing by people. London: Marion Boyars.

Ward, C. 2000. Anarchy and architecture: a personal record, in J. Hughes, S. Sadler (Eds.). Non-plan: essays on freedom, participation and change in modern architecture and planning. Oxford: Architectural Press, 44-51.

\section{MALCOLM MILES}

Professor of Cultural Theory in The School of Architecture, Design and Environment at the University of Plymouth, Drake Circus, Plymouth PL4 8AA, UK.

E-mail:M.F.Miles@plymouth.ac.uk

He is author of Eco-aesthetics: art, literature and architecture in a period of climate change (forthcoming 2014), Herbert Marcuse: an aesthetics of liberation (2011) and Cities and Cultures (2007), and has contributed to journals including Urban Studies, Cultural Geographies and The Journal of Architecture. His current research is in a critical reappraisal of the cultural turn in urbanism since the 1980s, and a reconsideration of modernism in art, literature and architecture. 